\title{
Protection of Human Lung Cells against Hyperoxia Using the DNA Base Excision Repair Genes hogg1 and Fpg
}

\author{
Min Wu, Ying-Hui He, Masayoshi Kobune, Yi Xu, Mark R. Kelley, and William J. Martin II \\ Division of Pulmonary, Allergy, Critical Care, and Occupational Medicine, Department of Medicine; Section of Hematology/Oncology, \\ Department of Pediatrics, Herman B. Wells Center for Pediatrics Research; and Department of Biochemistry and Molecular Biology, \\ Indiana University School of Medicine, Indianapolis, Indiana
}

\begin{abstract}
Hyperoxia causes pulmonary toxicity in part by injuring alveolar epithelial cells. Previous studies have shown that toxic oxygenderived species damage DNA and this damage is recognized and repaired by either human enzyme 8-oxoguanine DNA glycosylase (hOgg1) or Escherichia coli enzyme formamidopyrimidine DNA glycosylase (Fpg). To determine whether these DNA repair proteins can reduce $\mathrm{O}_{2}$-mediated DNA damage in lung cells, A549 lung epithelial cells were transduced with either hOgg1 or Fpg using a retroviral vector containing enhanced green fluorescent protein. Expression of each gene in the transduced cells was confirmed by fluorescent microscopy, Northern blotting, Western blotting, and an enzymatic oligonucleotide cleavage assay. A549 cells expressing either hOgg1 or Fpg were protected from hyperoxia as evidenced by a decrease in DNA damage and a corresponding increase in cell survival. Further, we determined that overexpression of hOgg1 or Fpg partially mitigated the toxic effects of hydrogen peroxide in lung cells. Our data suggest that increased expression of DNA base excision repair genes might represent a new approach for protecting critical lung cells from the toxic effects of hyperoxia.
\end{abstract}

Keywords: oxygen toxicity; DNA damage; DNA repair; hydrogen peroxide

High concentrations of oxygen are often required to maintain normoxemia in acute lung injury; yet, hyperoxia is also a common cause of acute lung injury (1). Current evidence indicates that the damaging effects of oxygen are mediated by reactive oxygen species (ROS) such as the superoxide anion $\left(\mathrm{O}_{2}{ }^{-}\right)(2-4)$. Oxygen and ROS can damage alveolar epithelial cells, leading to loss of the alveolar capillary barrier function (5). Mechanisms of oxygen-mediated lung injury include lipid peroxidation of cell membrane, structural damage of key proteins, and depletion of cellular reducing agents such as the reduced form of nicotinamide adenine dinucleotide phosphate (6).

Hyperoxia has been thought to be a cause of DNA damage and mutagenesis for decades $(7,8)$. More recent studies indicate that oxidant-mediated lung injury is associated with DNA damage as evidenced by an increase in p53 and p53-related gene products (9-11). Nonetheless, it is not clear how DNA damage and acute lung injury are linked and whether repair of acute DNA damage will reduce lung cell injury.

Oxygen and other oxidizing agents cause DNA single- and double-strand breaks that may result in cell death $(12,13)$. The main products of oxygen-induced DNA damage are 8-oxo7,8-dihydro-2'-deoxyguanosine and imidazole ring-opened gua-

(Received in original form December 14, 2001; accepted in final form February 5, 2002) Supported by $\mathrm{NCl}$ grant PO1-CA75426 (W.J.M. and M.R.K.).

Correspondence and requests for reprints should be addressed to William J. Martin II, M.D., Division of Pulmonary, Allergy, Critical Care, and Occupational Medicine, 1001 W. 10th St., OPW 425, Indianapolis, IN 46202-2879.

Am J Respir Crit Care Med Vol 166. pp 192-199, 2002

DOI: 10.1164/rccm.200112-1300C

Internet address: www.atsjournals.org nine (Fapy-Gua), followed by imidazole ring-opened adenine (Fapy-Ade) and cytosine glycol (14). Generation of oxidative DNA damage is prevented by antioxidant enzymes such as catalase (14) and superoxide dismutase (14) by reducing the amount and toxicity of ROS.

Eukaryotes possess a number of DNA repair enzymes that can rapidly reverse DNA damage. One of the key DNA repair enzymes involved in the base excision repair (BER) pathway in human cells to reverse oxidant-mediated DNA damage is 8-oxoguanine DNA glycosylase (hOgg1) $(15,16)$. hOgg1 is a functional, but not structural, analog of the Escherichia coli formamidopyrimidine-DNA glycosylase (Fpg) $(17,18)$. hOgg1 removes 7,8-dihydro-8-oxoguanine (8-oxoG) and other oxidative guanine modifications from nuclear and mitochondrial DNA. hOgg1 is present in mitochondria as well as in nuclei of human cells (19), as mitochondrial DNA is even more prone to oxidant-mediated damage than nuclear DNA is $(20,21)$. Wilson and colleagues have reported that BER protein Ogg1 can repair mtDNA damage in human cells (22). Deletion of the Ogg1 gene results in accumulation of 8-oxoG and an increase in mutational risk $(23,24)$. Fpg repairs 8-oxo purines, FaPy purines, and the imidazole ring-opened aminoethyl purines (25). Ogg1 deficiency in yeast, as well as Fpg deficiency in bacteria, results in a spontaneous mutator phenotype (26).

Although hOgg1 and Fpg are considered prime candidates for repair of oxidant-mediated DNA damage (27-31), it is not known whether these DNA repair proteins can protect mammalian lung cells from hyperoxia. Thus, we hypothesized that overexpression of hOgg1 or Fpg in lung cells might enhance resistance to hyperoxic injury. hOgg1 or Fpg was transduced into A549 alveolar epithelial cells using a retroviral vector pSF91. The cells transduced with either hOgg1 or Fpg were more resistant to hyperoxia when compared with vector control cells with less DNA damage, and enhanced cell survival. Further, overexpression of either hOgg1 or Fpg protected human lung cells from $\mathrm{H}_{2} \mathrm{O}_{2}$-induced DNA damage. These data suggest that rapid reversal of oxidant-mediated DNA damage may enhance resistance of lung cells to the toxic effects of hyperoxia.

\section{METHODS}

\section{Construction of Vectors}

The retroviral vector $\mathrm{pSF} 91 \mathrm{~N}$, based on murine stem cell virus backbone, was a gift of Dr. C. Baum, University of Hamburg, Germany (32). The bicistronic retroviral vector pSF91 was essentially constructed as described previously (33), with an internal ribosome entry site (IRES) upstream to the gene expressing enhanced green fluorescence protein (EGFP).

hOgg1 was a gift from Dr. S. Mitra (University of Texas Medical School, Galveston, TX). The hOgg1-6 cDNA was amplified by polymerase chain reaction (PCR) by primers $\left(5^{\prime}\right.$-ATCGAATTCCACCATHCCTGCCTGCCCGCGCGCTTCTGCCCA-3' and 5' -ATCGTCGACTTAGCCTTACGGCCCTTTGGA-3') to introduce a Kozak 
sequence at the $5^{\prime}$ end of the gene to increase translation efficiency (34). This product was digested with EcoRI and NotI and then ligated, using T4 DNA ligase, into pSF91. After transformation into DH5 $\alpha$ competent cells (Life Technologies, Gaithersburg, MD), colonies containing pSF91-hOgg1 were identified by PCR with the $5^{\prime}$-SF91 primer and the $3^{\prime}-\operatorname{hOgg} 1-6$ primer. The inserts were sequenced to confirm the integrity of the hOgg1-6 gene. The hOgg1-6 sequence is identical to that previously reported $(15,16)$, except that it lacks the $6 \mathrm{C}$-terminal codons (amino acids 317-322) of the wild-type gene. Eight micrograms of purified vector DNA was mixed with LipofectAMINE (Life Technologies) and transfected into phoenix-AMPHO cells. The viral supernatant was then used to infect the GP+E86 packaging cells. $\mathrm{GP}+\mathrm{E} 86$ cells exhibiting high fluorescent intensity were selected as stable producer populations. Virus supernatant (titers $>1 \times 10^{6}$ particles/ml) was filtered through a $0.45-\mu \mathrm{m}$ Acrodisc filter (Gelman Sciences, Ann Arbor, MI), and the filtered supernatant was incubated overnight with A549 cells in a solution containing $10 \mu \mathrm{g} / \mathrm{ml}$ polybrene (Sigma, St. Louis, MO). After 36 hours, the infected cells were selected by fluorescence-activated cell sorting.

The Fpg gene was cloned from HB101 E. coli cells using PCR primers that introduced EcoRI and SalI sites at the $5^{\prime}$ and $3^{\prime}$ termini of the gene, respectively $(31,33)$. The reaction conditions used for PCR were as described in the Tfl polymerase (Promega, Madison, WI) protocol. The PCR product and vector pGEX 4T-1 (Amersham Pharmacia Biotech, Piscataway, NJ) were digested with EcoRI and SalI, and the purified DNAs were ligated using T4 ligase (Life Technologies). After confirming the DNA sequence of the insert, the Fpg cDNA within the pGEX4T-1 vector was amplified in another round of PCR to introduce a Kozak sequence at the $5^{\prime}$ end of the gene (primers as in the foregoing). This PCR product was digested with EcoRI and SalI and ligated to linearized pSF91 vector using T4 ligase. The transient and stable producer cells were constructed and used to transduce A549 cells as in the foregoing.

\section{Northern Blot Analysis}

Total cellular RNA was isolated from cells $\left(5 \times 10^{6}\right)$ using the RNeasy Mini Kit (Qiagen, Valencia, CA) as per the manufacturer's instruc- tions. Total cellular RNA $(15 \mu \mathrm{g})$ was separated in a $1.2 \%$ formamide, agarose gel containing $18 \%$ formaldehyde and transferred onto Hybond-N nylon membrane (Amersham Pharmacia Biotech) using a $10 \times$ standard saline citrate solution $(1.5 \mathrm{M} \mathrm{NaCl}, 0.15 \mathrm{M}$ sodium citrate). The membrane was prehybridized in $10 \mathrm{ml}$ of Hyb-9 solution (Gentra Systems, Minneapolis, MN) for 1 hour. Full-length cDNA fragments of each gene were labeled with $\left[\alpha^{-32} \mathrm{P}\right] \mathrm{dCTP}$ (Amersham Pharmacia Biotech) using the Megaprime DNA Labeling System (Amersham Pharmacia Biotech) as per the manufacturer's protocol. After a 24-hour hybridization, the membrane was washed with low, medium, and high stringency washes, and visualized by autoradiography on Hyperfilm MP (Amersham Pharmacia Biotech).

\section{Western Blot}

Cell lysates were separated by sodium dodecyl sulfate-polyacrylamide gel electrophoresis $(10 \%)$, and then electroblotted to presoaked Immobilon-P membranes (Millipore, Bedford, MA) for 18 hours at 40 $\mathrm{mA}$ constant current in transfer buffer $(192 \mathrm{mM}$ glycine, $20 \mathrm{mM}$ Tris$\mathrm{HCl}$, and $15 \%$ methanol). The membranes were blocked by soaking in $1.5 \%$ bovine serum albumin in TBS-T $(50 \mathrm{mM}$ Tris- $\mathrm{HCl}, \mathrm{pH} 7.5$, $150 \mathrm{mM} \mathrm{NaCl}$, and $0.05 \%$ Tween-20) solution for 2 hours at room temperature. Each blot was incubated with rabbit polyclonal antibodies to hOgg1 (Novus Biologicals, Littleton, CO) at a dilution of 1:500 at room temperature for 1-1.5 hours. The membranes were briefly rinsed with deionized water and then washed five times with TBS-T (50 mM Tris- $\mathrm{HCl}, \mathrm{pH} 7.5,150 \mathrm{mM} \mathrm{NaCl}$, and $0.5 \%$ Tween 20 ) for 10 minutes per wash $(35,36)$. Secondary anti-rabbit peroxidase-conjugated antibodies (Sigma-Aldrich, St. Louis, MO) at 1:1,000 were then added and incubated with the membrane at room temperature for 45 minutes. Finally, the membrane was extensively washed as previously described and exposed on Kodak OMAT film using a chemiluminescence detection kit (Pierce, Rockford, IL).

\section{Enzyme Activity Assay}

The hOgg1 activity of transduced cells was quantified by detecting the cleavage of the 23-bp oligonucleotide substrate, containing a single 8-oxoguanine lesion 5'-GAA-CTA-GTGOATC-CCC-CGG-

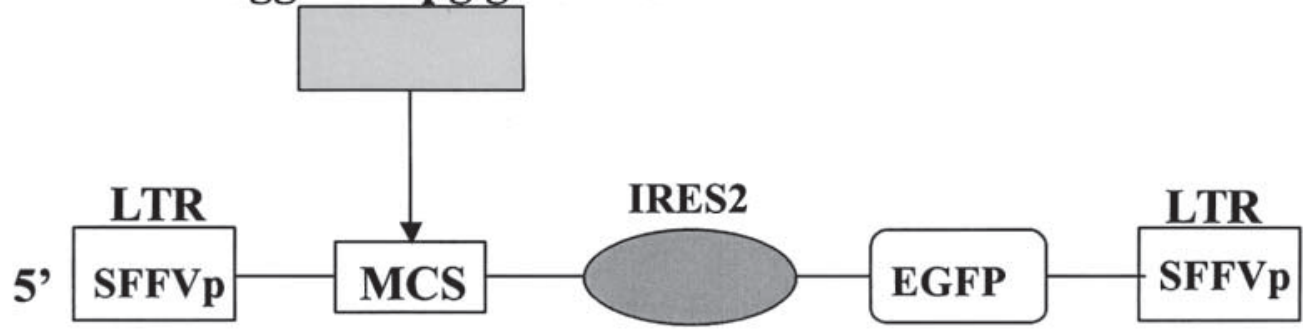

b

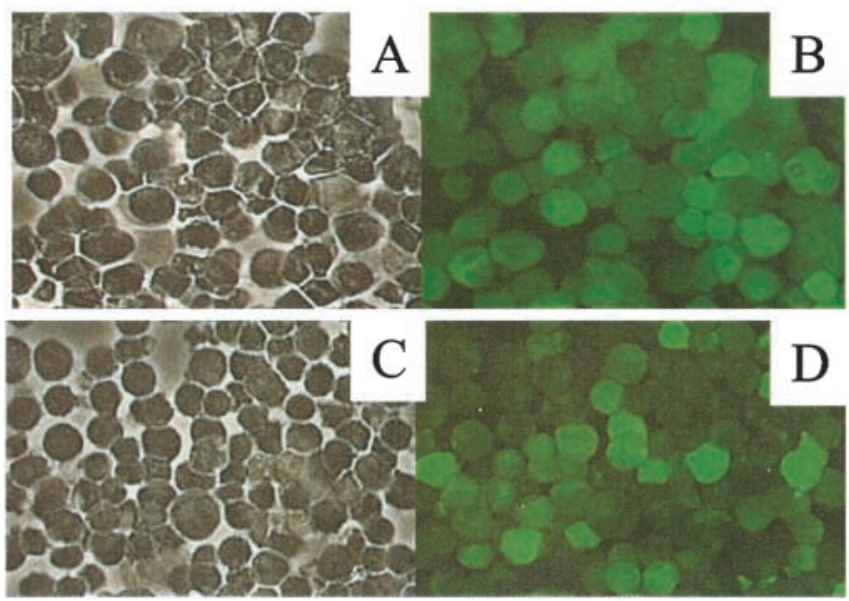

Figure 1. Construction and expression of retroviral vector containing the hOgg1 or E. coli Fpg coding regions. (a) Mammalian expression construct. From 5 '-end: $L T R$, spleen focus-forming virus (SFFV), multiple clone sites with the mIFN- $\gamma$ insert (EcoRI and Sall sites), internal ribosome entry site, EGFP, and $3^{\prime}$-end LTR. The transcript contains EGFP, the vector's splice donor and splice acceptor sites, and BER gene. (b) Expression of EGFP in A549 cells. Phase contrast $(A, C)$ and fluorescence $(B, D)$ microscopy of retroviraltransduced $A 549$ cells expressing EGFP/hOgg1 ( $A, B$-population; $C, D$-Clone 10) $(\times 400)$. 
GCT-GC-3' (Trevigen, Gaithersburg, MD). Cell lysates from control cells and cells transduced with hOgg1 (10- $\mu$ g protein samples) were reacted separately with 0.1 pmol of $\gamma-\left[{ }^{32} \mathrm{P}\right]$-dATP end-labeled 23-bp substrate at $37^{\circ} \mathrm{C}$ for 1 hour in $150 \mu \mathrm{l}$ of analysis buffer $(10 \mathrm{mM} \mathrm{N}-2$ hydroxythylpiperazine- $N^{\prime}$-2-ethane sulfonic acid-KOH, $\mathrm{pH} 7.4,10$ $\mathrm{mM} \mathrm{KCl}, 10 \mathrm{mM}$ ethylenediamine tetraacetic acid [EDTA], and 0.1 $\mathrm{mg} / \mathrm{ml}$ bovine serum albumin). The reaction was terminated by addition of $90 \%$ formamide loading buffer, and the samples were separated by denaturing sodium dodecyl sulfate polyacrylamide gel $(20 \%)$ electrophoresis. The gel was dried and exposed on X-ray film. The relative fractions of full length and cut substrate were determined by densitometric analysis using Kodak Analysis Software (Kodak, Rochester, NY). Fpg activity was detected as described previously using a 26-bp 8-oxoG-containing oligonucleotide, 5'-AATTCACCGGTACCOGTCTAGAATTCG-3' $(33,37)$.

\section{Hyperoxic Exposure}

A549 cells were grown in Dulbecco's modified Eagle's medium supplemented with penicillin $(100 \mathrm{U} / \mathrm{ml}) /$ streptomycin $(100 \mu \mathrm{g} / \mathrm{ml})$ and $10 \%$ fetal bovine serum, counted, and seeded on $100-\mathrm{mm}^{2}$ tissue culture dishes at a concentration of $8 \times 10^{4}$ cells $/ \mathrm{ml}$. Next day, the cells were subjected to hyperoxia in a NuAire $\mathrm{Nu}-3500$ cell culture incubator (NuAire Inc., Plymouth, MN). The incubator was infused with $95 \% \mathrm{O}_{2}-5 \% \mathrm{CO}_{2}$ for $12,24,48,72$, and 96 hours. Control A549 cells were incubated in room air-5\% $\mathrm{CO}_{2}$ for the same time intervals. $\mathrm{O}_{2}$ concentrations were monitored with a mini Oxygen Ted 60T meter (Teledyne Analytical Instruments, City of Industry, CA). $\mathrm{O}_{2}$ tension in culture medium was $647 \pm 9 \mathrm{~mm} \mathrm{Hg}$ (38). At each time point, the cells were harvested for assessment of DNA damage (Comet assay) and cell survival (colony forming assay).

\section{$\mathrm{H}_{2} \mathrm{O}_{2}$ Exposure}

A549 cells were plated into 60-mm dishes (five dishes) at a density of $3 \times 10^{5}$ cells/dish overnight. Next day, the cells were washed with phosphate-buffered saline (PBS) and incubated in the presence of $\mathrm{H}_{2} \mathrm{O}_{2}(0,100,200,400$, and $1,000 \mu \mathrm{M})$ at room temperature for 20 minutes. The cells were washed with PBS and used for assessment of DNA damage (Comet assay) and cell survival (colony forming assay).

\section{Comet Assay}

The Comet assay was performed according to the manufacturer's instructions using a CometAssay kit (Trevigen). Briefly, after exposure of cells to hyperoxia or $\mathrm{H}_{2} \mathrm{O}_{2}$, cells were washed with $\mathrm{Ca}^{2+}$ - and $\mathrm{Mg}^{2+}$-free PBS (Trevigen) at a concentration of $3 \times 10^{5} \mathrm{cells} / \mathrm{ml}$. The cell suspension was mixed with liquefied agarose at a 1:10 ( $\mathrm{vol} / \mathrm{vol}) \mathrm{ratio}$. A small aliquot of this mixture was immediately transferred onto the slide provided. After cell-lysis at $4^{\circ} \mathrm{C}$, slides were treated with alkali solution $(0.3$ $\mathrm{M} \mathrm{NaOH}, 1 \mathrm{mM}$ EDTA) for 60 minutes to unwind the double-stranded DNA. Slides were electrophoresed at $1 \mathrm{volt} / \mathrm{cm}$ for 10 minutes. After staining with SYBR green dye, samples were visualized and photographed by fluorescent microscopy using an Olympus BX60 Microscope System and Paxit software (MIS, Franklin Park, IL). Tail length was defined as the distance between the leading edge of the nucleus and the end of the tail. Seventy-five determinations were made for each sample using Adobe Photoshop software (Adobe System Inc., San Jose, CA).

\section{Colony Forming Assays}

After exposure of cells to hyperoxia or $\mathrm{H}_{2} \mathrm{O}_{2}$ as described in previous sections, $1 \mathrm{ml}$ of trypsin-EDTA $(0.25 \%: 1 \mathrm{mM})$ was added to each plate and incubated for 1 minute at $37^{\circ} \mathrm{C}$. After the incubation, $5 \mathrm{ml}$ of media containing fetal bovine serum was added and the cells were resuspended. Viability of the cells was determined by trypan blue $(0.4 \%$ $\mathrm{wt} / \mathrm{vol}$ ) exclusion. The viable cells were then counted and plated at various concentrations in triplicate on $100-\mathrm{mm}^{2}$ tissue culture plates. After 10-14 days, the colonies were stained with $1 \%$ methylene blue in $50 \%$ ethanol and enumerated.

\section{Statistical Analysis}

Experiments were performed in triplicate and repeated at least three times. Student's $t$ test and analysis of variance were performed, and significant difference was accepted at $\mathrm{p}<0.05$.

\section{RESULTS}

\section{Analysis of Transgene Expression}

To express DNA repair proteins in host cells, we subcloned the E. coli Fpg gene into pSF91 (Figure 1a) from pGEX 4T-1 Fpg. Vector pSF91, derived from murine stem cell virus backbone and LN-based retroviral vectors, was used for transduction of A549 cells and hematopoietic progenitor cells $(31,33)$ (Figure 1a). After selection for EGFP with fluorescence-activated cell sorting, more than $95 \%$ of the cells expressed EGFP (Figure 1b). The A549 cell population expressing EGFP (Figure 1b) was serially diluted to isolate single clones. Clone 10 is shown as representative of 27 clones selected (Figure 1b).

Northern blot analysis was performed to determine which clones contained actively transcribed transgenes and the relative expression level for each colony (Figure 2). hOgg1 transgene transcript is approximately $2 \mathrm{~kb}$, which includes the vector's splice donor and splice acceptor sites (Figure 2a). hOgg1 expression was also confirmed by Western blotting (Figure 2b). Various amounts of hOgg1 expression were demonstrated, as expected, at a molecular weight of $39 \mathrm{kD}$. Finally, the successful expression of hOgg1 was displayed in an enzymatic cleavage activity assay (Figure 2c). Similarly, the expression of Fpg in A549 cells was detected by Northern blot (Figure 2d). Enhanced Fpg expression in A549 cells was also confirmed by enzyme cleavage activity assay (data not shown).

\section{Protection from Hyperoxia}

A population of hOgg1-expressing A549 cells showed less DNA damage compared with vector-transduced control cells (Figure 3A). As shown in a representative picture of the Comet assay, exposure to hyperoxia for 3 days increased the tail length in vector-transduced cells, but this was not seen in hOgg1transduced cells (Figure 3B). Similarly, a population of A549 cells expressing Fpg was protected from hyperoxia (Figure

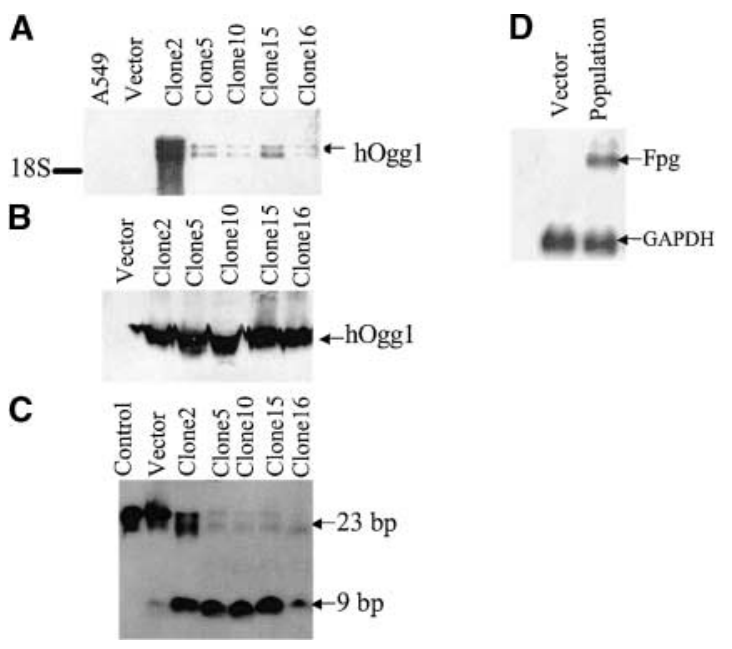

Figure 2. Expression and activity analysis of hOgg1-transduced A549 cells. (A) Northern blot analysis of hOgg1 mRNA. Clones 2, 5, 10, 15, and 16 expressing different amounts of hOgg1 mRNA. (B) Western blotting analysis of hOgg1 protein. Clones $2,5,10,15$, and 16 expressing different amounts of hOgg1 protein. (C) hOgg1 enzyme activity detected by oligonucleotide cleavage assay. Control, oligonucleotide without cleavages; Clones 2, 5, 10, 15, and 16 expressing different amounts of enzyme activity. Ten micrograms of cell-free extract reacted with $2.5 \mathrm{pM} \gamma$-[32P]-dATP-labeled 8-oxoguanine-containing 23-bp oligonucleotide for 60 minutes at $37^{\circ} \mathrm{C}$. The cleavage product of reaction was a 9-bp oligonucleotide. (D) Nouthern blot analysis of Fpg DNA expression. 

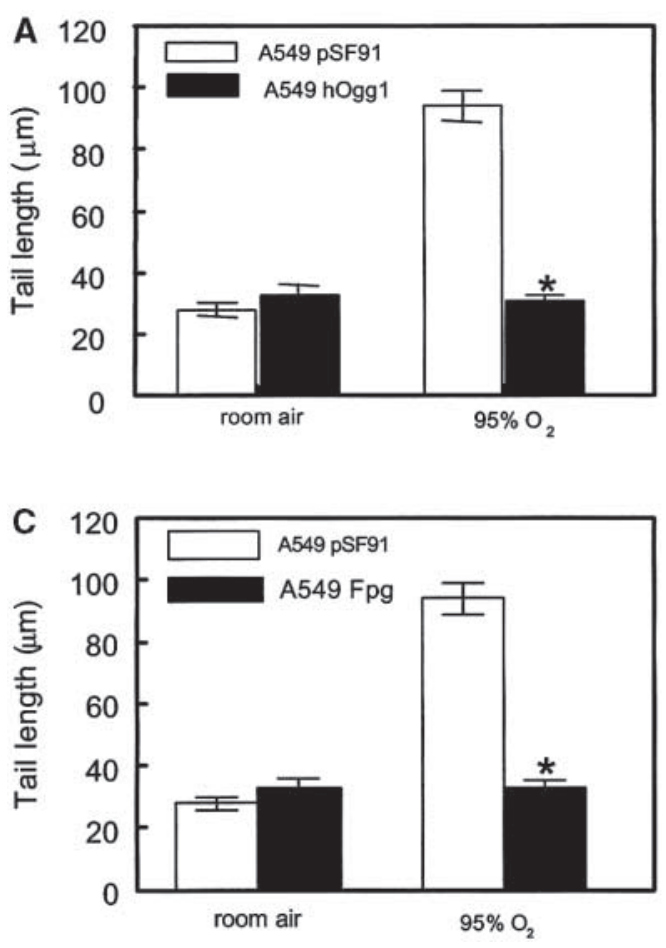

B

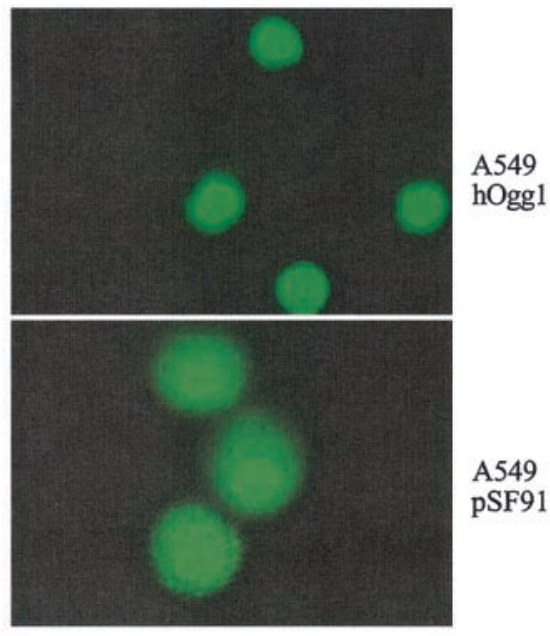

Figure 3. Effect of DNA BER protein expression in A549 cell population on $\mathrm{O}_{2}$-induced DNA damage. A549 cells expressing either hOgg1 or Fpg were incubated in $95 \% \mathrm{O}_{2}$ or room air for 72 hours. DNA damage was measured by Comet assay, and tail length was defined as the distance between the leading edge of the nucleus and the end of the tail. (A) A549 cell population expressing hOgg1. (B) Comet assay showing decreased DNA damage in hOgg1transduced A549 pop- ulation. (C) A549 cell population expressing Fpg. ${ }^{*} \mathrm{p}<0.05$, compared with the vector control.

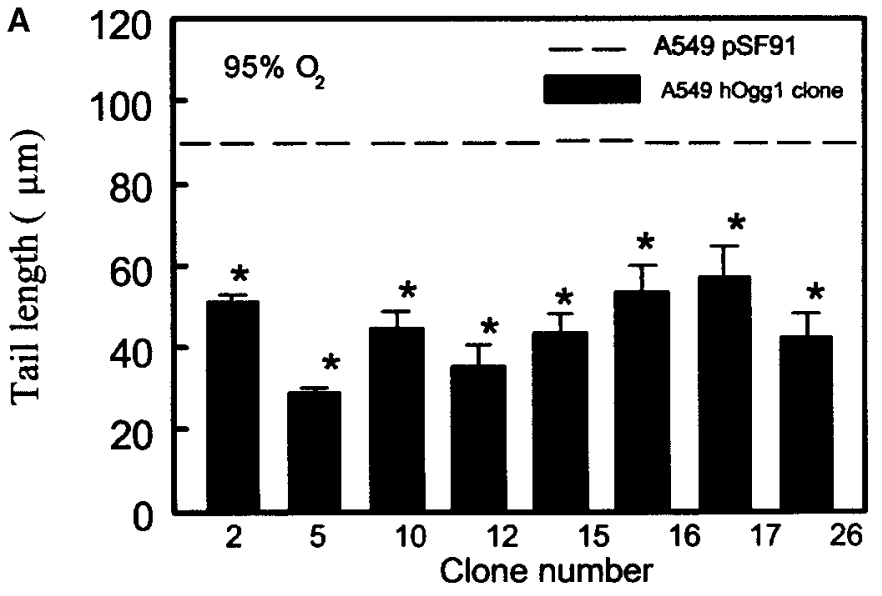

B

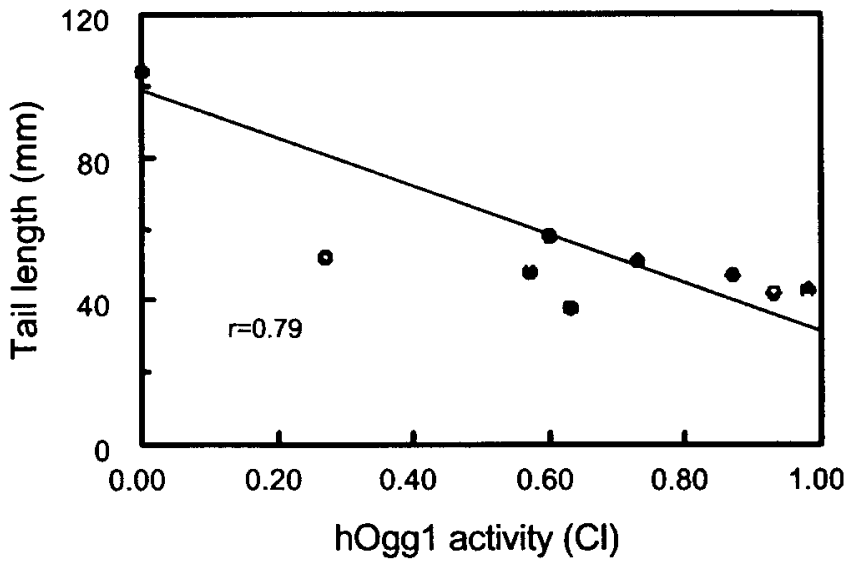

Figure 4. Effect of variable hOgg1 expression on DNA damage in hyperoxia. (A) Various A549 cell clones expressing different amounts of hOgg1 activity were incubated in $95 \% \mathrm{O}_{2}$ for 72 hours, and DNA damage was detected by Comet assay $\left({ }^{*} p<0.05\right.$, compared with the vector control). (B) Relationship between hOgg1 enzymatic activity and resistance to hyperoxia. hOgg1 activity (oligonucleotide cleavage assay)
3C). We generated 27 A549/hOgg1 clones that variably expressed the transgene hOgg1. Eight clones (2, 5, 10, 12, 15-17, and 26) were selected that expressed different levels of the hOgg1 transgene; yet, each clone demonstrated significant protection from DNA damage when incubated in hyperoxia (Figure 4A).

We assessed the relationship between hOgg1 activity and resistance to DNA damage during hyperoxia. The results showed that the levels of hOgg1 DNA repair activity in various A549 cell clones correlated with resistance to hyperoxic DNA damage in A549 cells $(r=0.79, \mathrm{p}<0.05)$ (Figure 4B). Although a correlation exists, hOgg1 activity in an individual A549 cell clone does not reliably predict the degree of protection from hyperoxia.

A549 cells expressing either hOgg1 or Fpg demonstrated longer survival compared with the vector-transduced control cells $(\mathrm{p}<0.05$, Figures $5 \mathrm{~A}$ and 5B). However, there were no significant differences between Fpg and hOgg1 in the ability to protect the cells from hyperoxia. Similarly, five hOgg1 clones $(2,5,10,15$, and 16) expressing significantly different levels of the hOgg1 transgene demonstrated a similar ability to sustain cell survival during hyperoxia (Figure 6A). The relationship between hOgg1 activity and cell survival demonstrated only a marginal correlation $(r=0.55, \mathrm{p}<0.05)$ (Figure 6B). Further, the correlation between DNA damage and cell survival in the hOgg1 clones was also marginal $(r=0.54, \mathrm{p}<0.05)$.

\section{Protection from $\mathrm{H}_{2} \mathrm{O}_{2}$}

To assess whether overexpression of BER genes would afford protection from $\mathrm{H}_{2} \mathrm{O}_{2}$, DNA damage and cell survival were assayed in lung cells overexpressing hOgg1 or Fpg in the pres-

and DNA damage (tail length measured by the Comet assay) were compared in A549 cell clones with variable expression of hOgg1 proteins. The hOgg1 activity was expressed as a cleavage index (CI) indicating the ratio of cleaved oligonucleotide to total oligonucleotide. 
ence or absence of $\mathrm{H}_{2} \mathrm{O}_{2}$. Overexpression of hOgg1 or Fpg significantly protected against DNA damage by $\mathrm{H}_{2} \mathrm{O}_{2}(0-1,000$ $\mu \mathrm{M})$ compared with the vector-transduced control cells $(\mathrm{p}<$ 0.05 , Figures 7A and 7B). Further, overexpression of hOgg1 partially enhanced cell survival in the presence of $\mathrm{H}_{2} \mathrm{O}_{2}(200$ and $1,000 \mu \mathrm{M})$ compared with the vector-transduced control cells $(p<0.05)$, whereas overexpression of Fpg did not enhance cell survival (Figures 7C and 7D). These data suggest that $\mathrm{H}_{2} \mathrm{O}_{2}$ might injure DNA of lung cells in a manner different from hyperoxia, and that the protective effects of BER proteins such as hOgg1 or Fpg on cell survival also differ.

\section{DISCUSSION}

We report a successful reduction in oxygen toxicity to lung cells by overexpression of BER repair proteins in these cells. Using an improved bicistronic retroviral vector $(33,39)$, we were able to transduce lung epithelial cells with either hOgg1 or Fpg DNA to achieve protein overexpression with each transgene. Overexpression of hOgg1 or Fpg protected the lung cells from hyperoxia-induced injury as demonstrated by either DNA damage or cell survival assays. This is the first study to show that overexpression of DNA BER proteins can be protective from oxygen toxicity in lung cells.

High concentrations of oxygen likely damage DNA of lung cells by forming an array of reduced ROS $(9,13)$. Evidence that DNA is a target for this damage is provided by the increase in DNA damage-inducible proteins such as p53 and p21 in the lung during hyperoxia $(10,13,40)$. In a manner similar to hyperoxia, bleomycin induces p53 and p21 expression, and this has been localized to type II alveolar epithelial cells in the lung (11). Of interest, hyperoxia is a frequently suspected
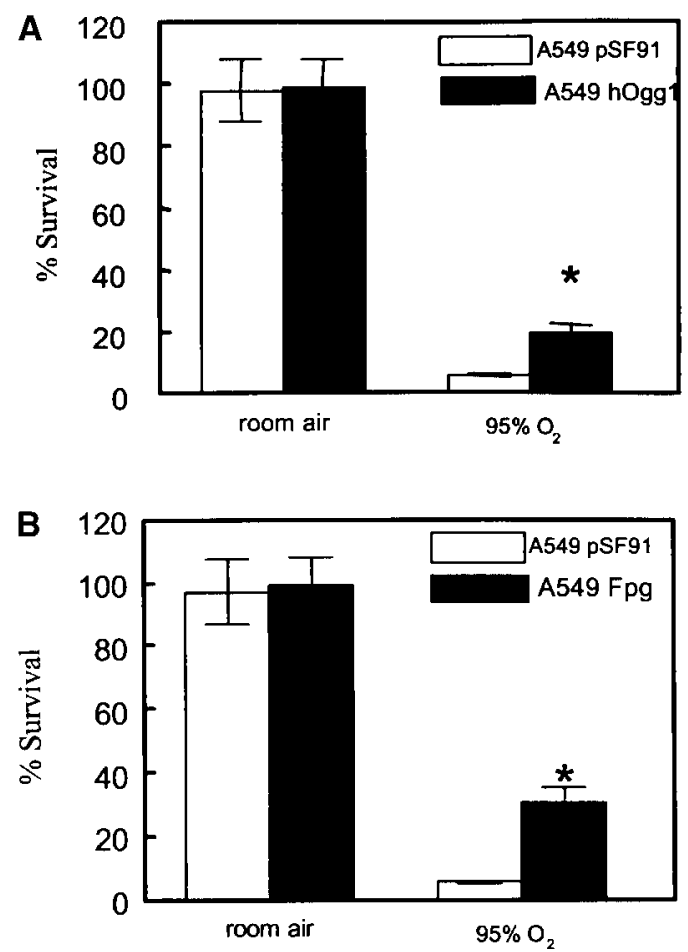

Figure 5. Effect of DNA BER protein expression on cell survival. A549 cells expressing hOgg1 or Fpg were incubated in $95 \% \mathrm{O}_{2}$, and cell survival was measured by colony forming assay. Cell survival was expressed as percentage of surviving colonies in hyperoxia to surviving colonies in room air. (A) A549 cell population expressing hOgg1. (B) A549 cell population expressing Fpg. ${ }^{*} p<0.05$, compared with the vector control. cofactor in clinical bleomycin toxicity (41). Bleomycin generates DNA lesions typical of the injury/repair cycle associated with oxidant damage (42). Widespread injury to the alveolar epithelium by hyperoxia or drugs may jeopardize the integrity of the lung. Type II cell injury and death is a catastrophic event for the alveolar unit as the type II cell is the progenitor of the type I alveolar epithelial cell (43) and is the major source of pulmonary surfactant proteins (44). New strategies are needed to protect alveolar epithelial cells from $\mathrm{O}_{2}$ toxicity. Our study suggests one approach to achieving protection is to rapidly reverse $\mathrm{O}_{2}$-induced DNA damage (Figure 8).

Recognition and removal of 8-oxoguanine residues from DNA is dependent on similar enzymes in bacterial and eukaryotic cells. The Fpg and hOgg1 DNA glycosylases recognize and initiate repair of 8-oxoguanine and formamidopyrimidine lesions produced by oxidative and alkylative DNA damage, respectively. The BER genes release the modified base from the sugar molecule of a nucleotide leaving an apurinic/apyrimidinic (AP) site in the DNA (45). After release of the damaged bases, downstream enzymes, including AP endonucleases (Ape1), DNA polymerase- $\beta$, and DNA ligase, continue the repairing process by filling and sealing the gap $(26,45)$.

Both hOgg1 and Fpg have AP lyase activity for removing 5 '-terminal deoxyribose phosphate flanking the DNA strand breaks next to abasic sites (46), although Fpg is more active in this respect than hOgg1 (47). Recent studies have shown that hOgg1 is a strong glycosylase but a much weaker AP lyase (47). It has been suggested that hOgg1 acts with other members of the BER pathway, namely the major AP endonuclease (Ape1/ref-1) or $\beta$-polymerase, to augment its inherent low lyase activity during hydrolytic processing of the AP site (47). This has been confirmed for the human T-G mismatch glycosylase that is dislocated by Ape1/ref-1 (48). However, enzymes downstream to hOgg1 may be rate-limiting in human
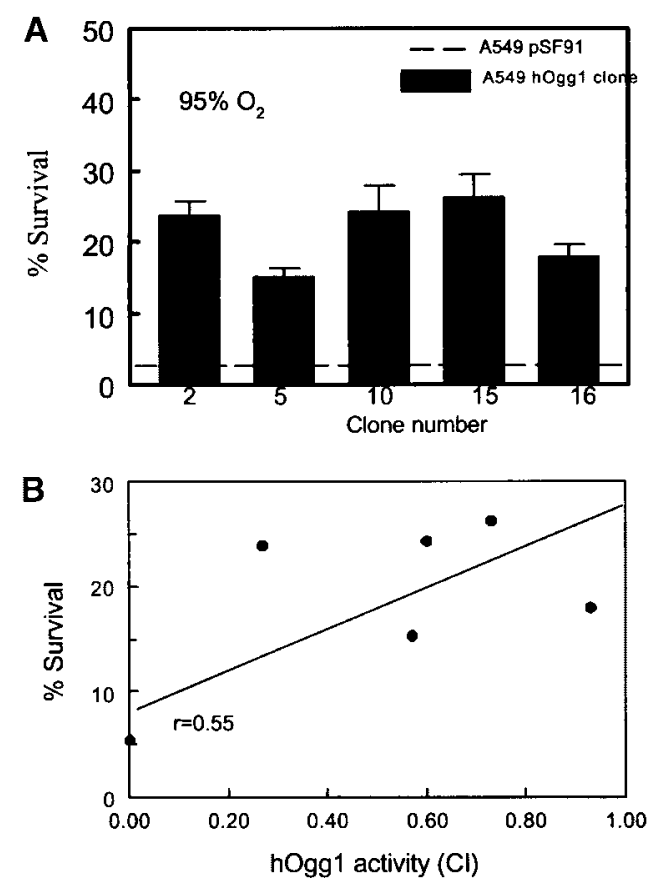

Figure 6. Effect of variable hOgg1 expression on cell survival in hyperoxia. (A) A549 cell clones expressing different amounts of hOgg1 were incubated in hyperoxia, and cell survival was measured by colony forming assay ( ${ }^{*} p<0.05$, compared with the vector control). (B) Relationship between hOgg1 enzymatic activity and resistance to hyperoxiainduced toxicity $(r=0.55, \mathrm{p}<0.05)$. 
A

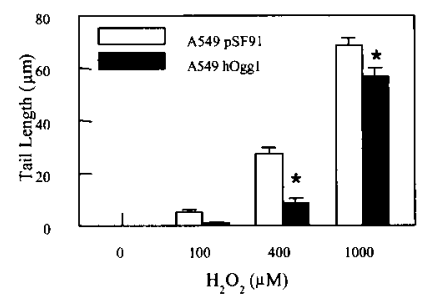

B

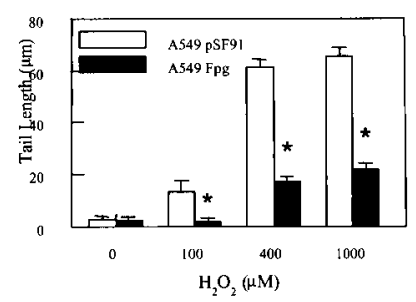

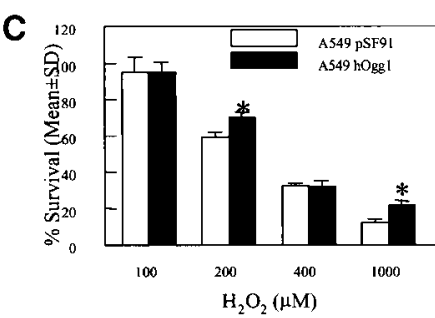

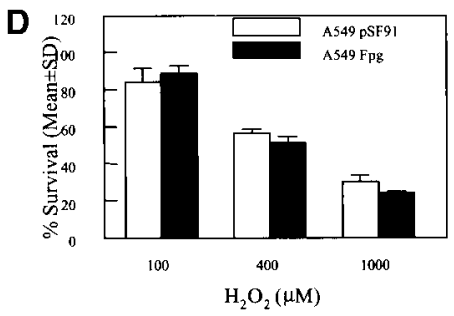

Figure 7. Protection from hydrogen peroxide-induced toxicity. Detection of DNA damage by the Comet assay: $(A)$ A549 cell population expressing hOgg1. (B) A549 cell population expressing Fpg. Detection of cell survival by the colony forming assay: (C) A549 cell population expressing hOgg1. (D) A549 cell population expressing Fpg. ${ }^{*} p<0.05$, compared with the vector control. cells $(31,49)$. It would be interesting to determine if increased expression of these downstream enzymes (Ape1/ref-1 and/or $\beta$-polymerase) will augment cell survival with coexpression of either hOgg1 or Fpg (31).

Our studies also demonstrate that cells overexpressing hOgg1 or Fpg were protected from the cytotoxic effects of exposure to $\mathrm{H}_{2} \mathrm{O}_{2}$. Among various lesions associated with oxidative DNA damage, 8-oxoG is the most important because of its abundance and mutagenicity. 8-oxoG and formamidopyrimidine are both substrates for Fpg and hOgg1 (50); however, recent studies have shown that the rate of excision of 7-methyl-formamidopyrimidine by hOgg1 is less than that of Fpg (51). hOgg1 and Fpg exhibit both $N$-glycosylase and $3^{\prime}$ and $5^{\prime}$ $\beta$-lyase activities for the removal of deoxyribose phosphate. Therefore, protection against $\mathrm{H}_{2} \mathrm{O}_{2}$ as evidenced in our study might be mediated by these other activities.

Although exposure to $\mathrm{H}_{2} \mathrm{O}_{2}$ is often used as a surrogate for ROS damage generated during hyperoxia, it is unclear if $\mathrm{H}_{2} \mathrm{O}_{2}$ causes a similar type of DNA damage. Studies in Chinese hamster ovary cells revealed that $\mathrm{H}_{2} \mathrm{O}_{2}$ produces mutagenic single-strand DNA damage, whereas hyperoxia causes sister chromatid exchanges and other chromosome aberrations (52). Iron chelators enhance survival of cells exposed to $\mathrm{H}_{2} \mathrm{O}_{2}$, but not when exposed to hyperoxia (53). The toxicity of $\mathrm{H}_{2} \mathrm{O}_{2}$ is probably dependent on the formation of hydroxyl radicals $\left({ }^{\bullet} \mathrm{OH}\right)$ through the Fenton reaction, as scavengers of ROS reduce ${ }^{\circ} \mathrm{OH}$ formation and prevent the lethal action of $\mathrm{H}_{2} \mathrm{O}_{2}$ $(13,54)$. However, hydrogen peroxide has direct effects on redox-signaling pathways, independent of hydroxyl radical formation (55).

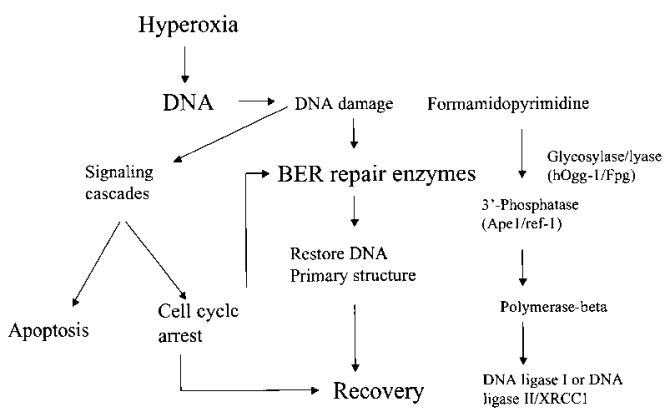

Figure 8. Hyperoxia: possible mechanisms of DNA damage and repair.
Although overexpression of BER proteins in lung cells protected from hyperoxia-induced DNA damage, it appears that BER proteins were less effective in protecting the cells from cell death. These findings are consistent with a role for DNA damage to be a contributing but not sole mechanism of hyperoxia-induced cell death. Apoptosis is generally considered to be the predominant mode of cell death from oxidative insults (56), which is controlled by complex signaling involving many regulatory proteins such as DNA damage-inducible proteins, proinflammatory factors, and cell cycle regulation kinases (57). However, necrosis during acute lung injury is also observed, particularly in A549 cells under hyperoxic condition (58), suggesting a dual mode of cell death (59). Other factors such as cell types and confluence state may determine the mode of cell death (60). Thus, we speculate that enhanced expression of BER proteins in A549 cells may protect from one type of hyperoxia-induced cell injury but not another. A limitation to the use of A549 cells is that they might also not accurately reflect the degree of DNA damage or repair that occurs to alveolar epithelial cells in vivo.

In summary, we have been able to successfully reduce hyperoxia-induced DNA damage to lung cells by overexpression of DNA BER protein hOgg1 or Fpg. This is the first study to demonstrate that DNA BER proteins have protective effects on reducing $\mathrm{O}_{2}$ toxicity in lung cells. Our data suggest that increased expression of DNA BER genes might represent a new approach for protecting critical lung cells from the toxic effects of hyperoxia.

Acknowledgment: The authors thank Dr. David A. Williams for beneficial discussion and Dr. Christopher Baum of University of Hamburg for the pSF vector. They also thank Patricia A. Smith for technical help and Julia L. Valente for editing assistance.

\section{References}

1. Deneke SM. Oxygen toxicity of the lung. Br J Anaesth 1982;54:737-749.

2. Fridovich I. Superoxide dismutase. Adv Enzymol 1974;41:35-97.

3. Taylor AE, Matalon S, Ward P. Physiology of oxygen radicals. Bethesda, MD: American Physiology Society; 1986. p. 313.

4. Martin WJ II, Gadek JE, Hunninghake GW, Crystal RG. Oxidant injury of lung parenchymal cells. J Clin Invest 1981;68:1277-1288.

5. Sorokin SP. Properties of alveolar cells and tissues that strengthen alveolar defenses. Arch Intern Med 1970;126:450-463.

6. Jackson RM. Pulmonary oxygen toxicity. Chest 1985;88:900-905.

7. Fenn WO, Gerschman R, Gilbert DL, Terwilliger DE, Tothran FV. Mutagenic effects of high oxygen tension on E. coli. Proc Natl Acad Sci USA 1957;43:1027-1032.

8. Conger A, Fairchild L. Breakage of chromosomes by oxygen. Proc Natl Acad Sci USA 1952;38:289-299. 
9. Barazzone C, Horowitz S, Donati YR, Rodriguez I, Piguet PF. Oxygen toxicity in mouse lung: pathways to cell death. Am J Respir Cell Mol Biol 1998;19:573-581.

10. O'Reilly MA, Staversky RJ, Watkins RH, Finkelstein JN. Exposure to oxygen induces p53 expression in mouse lung epithelium. Am J Respir Cell Mol Biol 1998;18:43-50.

11. Mishra A, Doyle NA, Martin WJ II. Bleomycin-mediated pulmonary toxicity evidence for a p53-mediated response. Am J Respir Cell Mol Biol 2000;22:543-549.

12. Olive PL. The role of DNA single- and double-strand breaks in cell killing by ionizing radiation. Radiat Res 1998;150:S42-S51.

13. O'Reilly MA. DNA damage and cell cycle checkpoints in hyperoxic lung injury: breaking to facilitate repair. Am J Physiol Lung Cell Mol Physiol 2001;281:L291-L305.

14. Breimer LH. Molecular mechanisms of oxygen radical carcinogenesis and mutagenesis: the role of DNA base damage. Mol Carcinog 1990; 3:188-197.

15. Rosenquist TA, Zharkov DO, Grollman AP. Cloning and characterization of a mammalian 8-oxoguanine DNA glycosylase. Proc Natl Acad Sci USA 1997;94:7429-7434.

16. Radicella JP, Dherin C, Desmaze C, Fox MS, Boiteux SF. Cloning and characterization of $h O G G 1$, a human homolog of the $O G G 1$ gene of Saccharomyces cerevisiae. Proc Natl Acad Sci USA 1997;94:80108015.

17. Friedberg EC, Walker GC, Siede W. DNA repair and mutagenesis. Washington, DC: ASM Press; 1995.

18. Boiteux S, O'Connor TR, Lederer F, Gouyette A, Laval J. Homogeneous Escherichia coli FPG protein: a DNA glycosylase which excises imidazole ring-opened purines and nicks DNA at apurinic/apyrimidinic sites. J Biol Chem 1990;265:3916-3922.

19. Nakabeppu Y. Regulation of intracellular localization of human MTH1, OGG1, and MYH proteins for repair of oxidative DNA damage. Prog Nucleic Acid Res Mol Biol 2001;68:75-94.

20. Yakes FM, Van Houten B. Mitochondrial DNA damage is more extensive and persists longer than nuclear DNA damage in human cells following oxidative stress. Proc Natl Acad Sci USA 1997;94:514-519.

21. Grishko V, Solomon M, Wilson GL, LeDoux SP, Gillespie MN. Oxygen radical-induced mitochondrial DNA damage and repair in pulmonary vascular endothelial cell phenotypes. Am J Physiol Lung Cell Mol Physiol 2001;280:L1300-L1308.

22. Dobson AW, Xu Y, Kelley MR, LeDoux SP, Wilson GL. Enhanced mtDNA repair and cellular survival following oxidative stress by targeting the hOGG repair enzyme to mitochondria. J Biol Chem 2000; 275:37518-37523.

23. Minowa O, Masanori Hirano T, Monden Y, Nakai S, Fukuda M, Itoh M, Takano H, Hippou Y, Aburatani H, Masumura K, et al. Mmh/Ogg1 gene inactivation results in accumulation of 8-hydroxyguanine in mice. Proc Natl Acad Sci USA 2000;97:4156-4161.

24. Klungland A, Rosewell I, Hollenbach S, Larsen E, Daly G, Epe B, Seeberg E, Lindahl T, Barnes DE. Accumulation of premutagenic DNA lesions in mice defective in removal of oxidative base damage. Proc Natl Acad Sci USA 1999;96:13300-13305.

25. Karakaya A, Jaruga P, Bohr VA, Grollman AP, Dizdaroglu M. Kinetics of excision of purine lesions from DNA by Escherichia coli Fpg protein. Nucleic Acids Res 1997;25:474-479.

26. Hansen WK, Kelley MR. Review of mammalian DNA repair and translational implications. J Pharmacol Exp Ther 2000;295:1-9.

27. Wood RD. DNA repair in eukaryotes. Annu Rev Biochem 1996;65: 135-167.

28. Cadet J, Bourdat AG, D'Ham C, Duarte V, Gasparutto D, Romieu A, Ravanat JL. Oxidative base damage to DNA: specificity of base excision repair enzymes. Mutat Res 2000;462:121-128.

29. Monden Y, Arai T, Asano M, Ohtsuka E, Aburatani H, Nishimura S. Human MMH (OGG1) type 1a protein is a major enzyme for repair of 8-hydroxyguanine lesions in human cells. Biochem Biophys Res Commun 1999;258:605-610.

30. Gill RD, Cussac C, Souhami RL, Laval F. Increased resistance to $\mathrm{N}, \mathrm{N}^{\prime}, \mathrm{N}^{\prime \prime}$-triethylenethiophosphoramide (thiotepa) in cells expressing the Escherichia coli formamidopyrimidine-DNA glycosylase. Cancer Res 1996;56:3721-3724.

31. Xu Y, Hansen WK, Rosenquist TA, Williams DA, Limp-Foster M, Kelley MR. Protection of mammalian cells against chemotherapeutic agents thiotepa, 1,3- $N, N^{\prime}$-bis(2-chloroethyl)- $N$-nitrosourea, and mafosfamide using the DNA base excision repair genes Fpg and $\alpha$-hOgg1: implications for protective gene therapy applications. J Pharmacol Exp Ther 2001;296:825-831.

32. Hildinger M, Abel KL, Ostertag W, Baum C. Design of $5^{\prime}$ untranslated sequences in retroviral vectors developed for medical use. $J$ Virol 1999;73:4083-4089.

33. Kobune M, Xu Y, Baum C, Kelley MR, Williams DA. Retrovirus-mediated expression of the base excision repair proteins, formamidopyrimidine DNA glycosylase or human oxoguanine DNA glycosylase, protects hematopoietic cells from $N, N^{\prime}, N^{\prime \prime}$-triethylenethiophosphoramide (thioTEPA)-induced toxicity in vitro and in vivo. Cancer Res 2001;61:5116-5125.

34. Kozak M. Point mutations define a sequence flanking the AUG initiator codon that modulates translation by eukaryotic ribosomes. Cell 1986; 44:283-292.

35. Wu M, Brown WL, Stockley PG. Cell-specific delivery of bacteriophageencapsidated ricin A chain. Bioconjug Chem 1995;6:587-595.

36. Wu M, Kelley MR, Hansen WK, Martin WJ II. Reduction of BCNU toxicity to lung cells by high-level expression of $O^{6}$-methylguanine-DNA methyltransferease. Am J Physiol Lung Cell Mol Physiol 2001;280: L755-L761.

37. He Y, Xu Y, Wu M, Kobune M, Kelley MR, Martin WJ II. E. coli FPG and human Ogg1 reduce DNA damage and cytotoxicity by BCNU in human lung cells. Am J Physiol Lung Cell Mol Physiol 2001;182:L50-L55.

38. Martin WJ II, Kachel DL. Oxygen-mediated impairment of human pulmonary endothelial cell growth: evidence for a specific threshold of toxicity. J Lab Clin Med 1989;113:413-421.

39. Wu M, Hussain S, He HY, Pasula R, Smith PA, Martin WJ II. Genetically engineered macrophages expressing IFN- $\gamma$ restore alveolar immune function in scid mice. Proc Natl Acad Sci USA 2001;98:1458914594.

40. O'Reilly MA, Staversky RJ, Watkins RH, Reed CK, de Mesy Jensen KL, Finkelstein JN, Keng PC. The cycline-dependent kinase inhibitor p21 protects the lung from oxidative stress. Am J Respir Cell Mol Biol 2001;24:703-710.

41. Goad MEP, Tryka AF, Witschi HP. Acute respiratory failure induced by bleomycin and hyperoxia: pulmonary edema, cell kinetics, and morphology. Toxicol Appl Pharmacol 1987;90:10-22.

42. He Y, Wu M, Kobune Y, Xu Y, Kelley MR, Martin WJ II. Expression of yeast apurinic/apyrimidinic endonuclease (APN1) protects lung epithelial cells from bleomycin toxicity. Am J Respir Cell Mol Biol 2001; 25:692-698.

43. Adamson IYR, Bowden DH. The type II cell as progenitor of alveolar epithelial regeneration. Lab Invest 1974;30:35-42.

44. Crouch E, Wright JR. Surfactant proteins A and D and pulmonary host defense. Annu Rev Physiol 2000;63:521-554.

45. Seeberg E, Eide L, Bjoras M. The base excision repair pathway. Trends Biochem Sci 1995;20:391-397.

46. Graves RJ, Felzenszwalb I, Laval J, O'Connor TR. Excision of 5'-terminal deoxyribose phosphate from damaged DNA is catalyzed by the Fpg protein of Escherichia coli. J Biol Chem 1992;267:14429-14435.

47. Zharkov DO, Rosenquist TA, Gerchman SE, Grollman A. Substrate specificity and reaction mechanism of murine 8-oxoguanine-DNA glycosylase. J Biol Chem 2000;275:28607-28617.

48. Waters TR, Gallinari P, Jiricny J, Swann PF. Human thymine DNA glycosylase binds to apurinic sites in DNA but is displaced by human apurinic endonuclease 1. J Biol Chem 1999;274:67-74.

49. Limp-Foster M, Kelley MR. DNA repair and gene therapy: implications for translational uses. Environ Mol Mutagen 2000;35:71-81.

50. Karahalil B, Girard PM, Boiteux S, Dizdaroglu M. Substrate specificity of the Ogg1 protein of Saccharomyces cerevisiae: excision of guanine lesions produced in DNA by ionizing radiation- or hydrogen peroxide/metal ion-generated free radicals. Nucleic Acids Res 1998; 26:1228-1233.

51. Asagoshi K, Yamada T, Terato H, Ohyama Y, Monden Y, Arai T, Nishimura $\mathrm{S}$, Aburatani H, Lindahl T, Ide H. Distinct repair activities of human 7,8-dihydro-8-oxoguanine DNA glycosylase and formamidopyrimidine DNA glycosylase for formamidopyrimidine and 7,8-dihydro-8-oxoguanine. J Biol Chem 2000;275:4956-4964.

52. Gille JJ, Mullaart E, Vijg J, Leyva AL, Arwert F, Joenje H. Chromosomal instability in an oxygen-tolerant variant of Chinese hamster ovary cells. Mutat Res 1989;219:17-28.

53. Gille JJ, van Berkel CG, Joenje H. Effect of iron chelators on the cytotoxic and genotoxic action of hyperoxia in Chinese hamster ovary cells. Mutat Res 1992;275:31-39.

54. Mello-Filho AC, Meneghini R. Iron is the intracellular metal involved in the production of DNA damage by oxygen radicals. Mutat Res 1991; 251:109-113.

55. Shackelford RE, Kaufmann WK, Paules RS. Cell cycle control, checkpoint mechanisms, and genotoxic stress. Environ Health Perspect 1999;107:5-24. 
56. Szumiel I. Monitoring and signaling of radiation-induced damage in mammalian cells. Radiat Res 1998;150:S92-S101.

57. Clement, A, Henrion-Caude A, Besnard V, Corroyer S. Role of cyclins in epithelial response to oxidants. Am J Respir Crit Care Med 2001; 164:S81-S84.

58. Kazzaz JA, Xu J, Palaia TA, Mantell L, Fein AM, Horowitz S. Cellular oxygen toxicity: oxidant injury without apoptosis. J Biol Chem 1996; 271:15182-15186.
59. Mantell LL, Horowitz S, Davis JM, Kazzaz JA. Hyperoxia-induced cell death in the lung-the correlation of apoptosis, necrosis, and inflammation. Ann N Y Acad Sci 1999;887:171-180.

60. Jyonouchi H, Sun S, Abiru T, Chareancholvanich S, Ingbar DH. The effects of hyperoxic injury and antioxidant vitamins on death and proliferation of human small airway epithelial cells. Am J Respir Cell Mol Biol 1998;19:426-436. 